\title{
Understanding Enforceability Challenges Facing Equality Rights Under Art. 27 of the Constitution of the Republic of Kenya
}

\author{
Peter Onyango Onyoyo \\ School of Law, University of Nairobi \\ *Corresponding Author: peter.onyango@uonbi.ac.ke
}

Copyright (C) 2014 Horizon Research Publishing All rights reserved.

\begin{abstract}
By illustrating the theoretical framework of equality rights the author seeks to explain some of the key challenges facing their enforceability and constitutionality in the Kenyan modern legal system. Under the Constitution of 2010, it is particularly emphasised that the State and its institutions must endeavour to enforce human rights and the rule of law for the betterment of the situation of living worth for human dignity in regard to the international minimum standards. It is in this light that this previewed article seeks to bring to juridical discussion the best understanding of equality rights and why many jurisdictions still fail to fully implement them. The research is not blind of similar difficulties faced in civilised nations and modern democracies but also makes substantive attempts to provide solution based on case by case analysis.
\end{abstract}

Keywords In/Equality of Rights, Status Quo, Human Rights, Constitutional Rights, Enforceability, Social Injustice, Market Economy and Socialism Theories

\section{Conceptualizing Equality Rights}

Equality Rights is one of the most debated topics and the most problematic discourse of human rights especially when it comes to discussing their enforcement and constitutionality. Mainstream human rights lawyers, learned judges and jurists still find challenges in understanding application of equality rights due to their irrelevance with true practice and experiences with difficult human rights litigations. Speaking of equality rights often sounds redundant, antique and contradictory, especially in matters concerning second generation of rights: economic, social and cultural rights.

The paradox is that no State has ever fully complied with equality rights under proscribed economic, social and cultural rights. Strange enough modern democracies and majoritarian thinkers are no longer driven by the aspirations of equality and fraternity but rather by inequality and individualism. 1

John Kennedy Galbraith made a substantive contribution to the emblematic question of enforceability of the equality rights in his work "The Culture of Contentment" quoted in the work of Michael Kenny. It claims that the contented represented the privileged minority elite but now the majority in the modern developed society is "contented" and that they ensure that society is ordered in their own interests 2 rendering equality rights irrelevant. This has eventually led to a dramatic decline of traditional egalitarianism 3 whose conviction was anchored on equality as uniformity in treatment or status by those in a position to affect them insisting on mathematical axiom, $1=1$. This is unachievable by human standards. There is a rolling back of fundamental principles underpinning the concept of benevolent States today leading to a conviction that the market trends should dictate economic policies. Such realities as unemployment, poverty, emigration, homelessness, environmental degradation are becoming acceptable with time. They are deemed to be consequences of necessary economic progress which can be dealt with through "incentives", bail-outs, and subsidies meant for the disadvantaged to maintain equilibrium in the market driven economies as has been demonstrated in the Euro zone and in the USA during the economic crunch of 2005.4

In essence there is no way we can understand equality rights without evaluating the politics and philosophy surrounding them. Cumulatively equality rights in the international order have intrinsic nexus with the great ideological politics based on two blocs, Capitalism v Communism. The two have divergent and convergent understandings of equality rights in terms of equal sharing of public resources, equitable distribution of wealth, justice and

\footnotetext{
1 MICHAEL KENNY "The Culture of Contentment".

2 IDEM.

3 JOHN RAWLS, A Theory of Justice, The Belkanap Press of Harvard University Press, USA, 1999, p. 472.

4 IDEM. See also JOHN RAWLS, A Theory of Justice, The Belkanap Press of Harvard University Press, USA, 1999, p. 19.
} 
projection of future development. 5

Capitalist States (the West) embraced market driven economies in their capitalist policies for means of production. Socialist-communist (the East) bloc preferred State-owned means of production. The latter prioritized social values as a way of the attainment of equality rights whereas the former validly believed in generation of wealth and how to accumulate it. Divergent opinion in the socialist conception of equality rights is based on State liabilities and responsibility in ensuring respect, promotion and enforcement of such rights. Instead the capitalist States embraced the need for competitiveness and market forces to improve domestic production and generation of more wealth to meet the needs of individuals. Equality of opportunity contends that people ought to be able to compete on equal terms or on a level playing ground.

The majority of modern democracies including ex-colonies have endorsed competitive market based theory to define their productivity and as means of enforcing equality human rights in their systems. 6 However, capitalist market oriented economy theory falls short of how accumulated wealth should be equitably distributed especially to the most disadvantaged individuals and at the same time avoiding fall-back to the trap of traditional egalitarianism theory of "incentives" or allocating funds for social welfare for the disadvantaged population which would make them socialists.

Two political blocs emerged: the "Conservatives" known as the leftist or socialists and the "Liberal Democrats" or capitalists known as rightists. Conservatives held that social values are essential for equal rights and emphasised on equitable distribution of wealth as means of achieving basic needs of the disadvantaged majority of society and eventually equality human rights. 7

Liberal-Democrats opposed to social welfare rights held that equality human rights according to them can be obtained through competitiveness and ability to generate income. 8

Both socialists and capitalists did not fully persuade the world opinion court since in each of them still the disparity and inequality elements are persistently reminiscent. Till today the two theories have not managed to satisfy the demands of equality rights through political claims. In this case it is important to look at the philosophical or jurisprudential account on equality human rights and its claims in light of Article 27 of the Constitution of Kenya.

It is from the jurisprudence other than political theory that we can understand the enforceability of equality human rights.9 Jurisprudential analysis of equality rights is a

5 See ADAM SMITH, The Wealth of Nations, Bantam Dell, New York, 2003, p. 422.

6 ADAM SMITH, The Wealth of Nations, Bantam Dell, New York, 2003, p. 422.

7 See J.K. GALBRAITH, The Affluent Society, Penguine Books Ltd., Great Britain, 1958, pp. $73 \mathrm{ff}$.

8 IDEM.

9 VICKI C. JACKSON, Constitutional Engagement in a Transnational Era, Oxford University Press, 2010, p. 2. See also DAVID KEANE \& YVONNE MCDERMOTT, The Challenge of Human Rights: Past, Present and Future, combination of both capitalist and socialist schools of thought. Both thoughts agree that equality rights are intrinsic and inherent rights that belong to each human being by virtue of being a member of human family. 10 It is from this converging ground that universality of equality rights, respect of human dignity and human rights have got into the mainstream of human rights law and, by large, in the Kenyan Constitution.

The United Nations Universal Declaration of Human Rights rules in its Art. 1, that All human beings are born free and equal in rights and dignity 11 is the best expression of the philosophy of equality rights. Every systematic legal analysis of equality rights shall anchor its rationalization of rights in the theoretical framework of international human rights. However, one needs to define equality rights before looking at their enforceability and constitutionality aspects.

\section{Understanding Equality Rights}

Given the divergent political understanding of equality rights and their challenges in practice, it is necessary to discuss the jurisprudence of equality rights. Equality is a perplexing concept of human rights and its definition cannot be expressed in one single principle. Equality Rights is a group of principles that is better understood under liberal egalitarianism theory. Traditionally, equality rights are interpreted in terms of: equality of basic needs, equal respect, economic equality, political equality, sexual, racial, ethnic and religious equality, which in themselves mean nothing unless illustrated within their correct jurisprudential context of human equality.

Human equality and equal rights have affinity at law. Both go hand in hand basing their ontology on human life and radical capacity which exists in the nature of the "person". 12 Human equality is contained by design in the nature of the person as found in the preamble of the UDHR, "Recognition of the inherent dignity and of the equal and inalienable rights of all members of the human family". The document adds that equality is the foundation of freedom, justice and peace in the world and the same has been echoed by John Rawls and other social justice jurists. 13

It is undisputable that the enforceability and constitutionality of equality rights is informed by French Revolution of 19th Century theory of égalité which by extension covers the meaning of historic liberal egalitarian movements in Europe by then making reference to equal distribution of primary goods that the society is able to produce. 14 It was the work of French legal sociologists such as Jean Rousseau, Compte and Emile Durkheim to

Edward Elgar Publishing Limited, Massachusetts, USA, 2012.

10DAVID KEANE \& YVONNE MCDERMOTT, The Challenge of Human Rights: Past, Present and Future, Edward Elgar Publishing Limited, Massachusetts, USA, 2012, pp. $2 \mathrm{ff}$.

11 IDEM.

12 ("UDHR.pdf," n.d.)

13 JOHN RAWLS, A Theory of Justice, The Belkanap Press of Harvard University Press, USA, 1999, p. 73.

14 IDEM, p. 472 
emphasize on the enforceability and constitutionality of equality rights. French school of thought admitted that human society is not equal and there is no equality rights without regulatory mechanism or social control system in place and that must be based on sovereignty or the State.

Mainstream sociology of law admits that pure equality rights in terms of equal shares of wealth or resources is a utopian ideal and cannot be realised by human standards. Equality among all humans is easy to legislate than to achieve in practice. Social inequality is deeply ingrained in some cultures and thus difficult to overcome through judicial systems. Liberal egalitarianism admits that there will always be major inequalities between people in their status, resources, work and power. What is justiciable is how such resources, work and power can be shared in a manner to meet minimum acceptable human rights standards. Human rights law holds that equality rights should be understood in the context of international minimum standards that respects human dignity, worth and rights. And it is the responsibility of the State to recognise, respect, promote and protect them. Art. 22 of the UDHR provides, "Everyone as a member of society, has the right to social security and is entitled to realization, through national effort and international co-operation..." a clause that is repeated in the Covenant of Economic, Social and Cultural Rights of 1966.

\section{Interface between Inequality \& Equality Rights}

It sounds contradictory that despite persisting in equality rights by the International Bill of Rights which assures entitlement of individuals to social and international order, still there is no single nation on earth that has fully adhered to principles. The Republic of Kenya for example is faced with numerous claims concerning the protection of human rights especially economic, social and cultural rights 15 in her advancing affluent economic trends. As a young democracy and a developing State, she is faced with substantive claims related to poverty and inequality data.

Such are claims related to gender equality, rising standard of living, basic minimum of benefits from the wealth process (guaranteed income, tenure security, social and economic security, abolition of poverty). 16 There are also claims related to the enjoyment of benefits on the basis of contribution and merit, claims related to participation, enlightenment (free primary education), 17 equal opportunity, basic degree of respect of individual human beings, meritorious contribution, basic equality of opportunity in the enjoyment of all values including allocation of public offices and accommodating every individual in the workforce. Most importantly, failure to have a proper equitable system to redress past

15 DR. PETER ONYANGO, Cultural Gap \& Economic Crisis in Africa, Fastprint Publishing, 2010, pp. 1ff. "Development of Culture".

16 See J.K. GALBRAITH, The Affluent Society, Penguine Books Ltd. Great Britain, 1958, p.75.

17 Op. Cit., p. 285. socio-economic and cultural injustices accommodating equitable persons of different ethnic diversities, social classes, variant health statuses, income status, sexual orientations and equitable distribution of national wealth. 18

Quoting from European experience, Kenya has been rated very low in terms of how it treats minority groups and disadvantaged communities within her jurisdiction. Disparities and discriminations are still felt across the national board even after the promulgation of the new constitution in 2010 which establishes several constitutional and statutory institutions to address the inequalities allegations through transitional justice. Paradoxically, like many other old democracies, institutional reforms are not providing immediate solution to equality of rights as stated in the following citation.

Despite laws and policy measures being developed at the European, national, and local levels,job-seeking immigrants and ethnic minorities still suffer unequal access and ethnic discrimination.This important volume divided into sections on discrimination, gender, equity policies, and diversity management compares several European labour markets, recommends methods for conducting further research and evaluates the actual effects of discrimination-combating policies. ${ }^{19}$

The question of un-redressed historical social injustice, failure thereto to come up with a working legal framework, reluctance to implement reports from relevant statutory and constitutional institutions, and failure to bring thereto, the State organs to justice form main part of contentions, abuses of power, corruption, impunity and social violence as can well be demonstrated under economic, social and cultural (in)equalities:

a) Economic inequality: The gap between the rich and the poor is increasingly widening. ${ }^{20}$ Pastoralists, farmers, business communities and elite all live in a situation that does not respect international minimum standards meant for all human beings. Allocations of public duties are prone to nepotism, political biasness and sycophancy rather than meritocracy and equity.

b) Social inequality: Art. 28 of the UDHR states that everyone as a member of society has the right to social and international order. Gender inequality, rights related to the disabled, failure to have social welfare rights, social work law, transgender equality, respect for sexual orientations, all reveal elements of inequality. Access to quality primary education (free primary education) and access to justice are still realities challenging the equality rights. Forced evictions of the landless and homeless still create more questions than answers. Pastoralist

18 Op. Cit., p. 75, See also Art. 27 of the Constitution of Kenya.

19 Journal of Ethnic and Migration Studies (2011),

Volume: 37, Issue: 10, Pages: 1701-1702.

20 J.K. GALBRAITH, The Affluent Society, Penguine Books Ltd., Great Britain, 1958, pp. 73ff. 
communities find themselves excluded from the entire social trends making equality unrealistic and unachievable.

At the Nairobi High Court a Constitutional Petition No. 160 of 2013 that involved Rose Wangui Mambo and 2 Others v Limuru Country Club and 17 Others [2014] eKLR reveals the following: At the centre of the controversy is a by-law allegedly made by a majority of the 2nd to 9th respondents as directors of the Club at a Board meeting held on 18th December 2012. The by-law has the effect of excluding the lady golf members from participating in the Golf General Meeting Election. The relevant part of the impugned by-law reads as follows; "The golf committee being a male only affair, only full male members with valid handicaps, and who are fully paid up, will be allowed to participate in the meeting and that lady golfers will attend the meeting as guests." 21 The Supreme Court in its majority opinion ruled the following: "This Court is fully cognisant of the distinct social imperfection which led to the adoption of Articles 27(8) and 81(b) of the Constitution: that in elective or other public bodies, the participation of women has, for decades, been held at bare nominal levels, on account of discriminatory practices, or gender-indifferent laws, policies and regulations. This presents itself as a manifestation of historically unequal power relations between men and women in Kenyan society.... Thus, the Constitution sets out to redress such aberrations, not just through affirmative action provisions such as those in Articles 27 and 81, but also by way of a detailed and robust Bill of Rights, as well as a set of "national values and principles of governance" [Article 10]."

c) Cultural inequality: The current Constitution of Kenya promotes cultural values and heritages of the Kenyan people but the existing laws in place are not yet fully compatible and in compliance with stipulated international minimum standards. Cultural institutions in Kenya still require well improved legislations and institutions that would adapt to human rights and international standards. 22 Management authorities and Boards are yet to come up with suitable criteria and effective frameworks that would abet legislative and judicial authorities.

\section{Describing Inequality}

Relating this discussion to the three key areas of economic, social and cultural rights grouped as second generation theory of human rights, it is mandatory, relevant and timely to look at each from the perspective of gender equality, social exclusion, ethnic disparity, health services equality, equal opportunity, equitable distribution of national and natural resources.

Kenyan effort to enforce equality rights under Art. 27 of

\footnotetext{
${ }^{21} \mathrm{http}: / /$ kenyalaw.org/caselaw/cases/view/95512/

22 (“CULTURAL INEQUALITY1.pdf," n.d.)
}

the Constitution can be traced back to colonial rule and anti-colonial mobilization legacy. ${ }^{23}$ Hyden in his writing opines that Statehood never existed in the sub-Saharan Africa before the colonial rule and modern States significantly lack African social roots. Such States were unable to shape up, economic, social and cultural activities in a manner that would be compatible with national development aspirations and human rights. ${ }^{24}$

By analogy, Kenya has not found a better solution to deal with her historical inequality allegations despite numerous efforts to compel her to comply with transitional justice criteria.25 Tangible attempts have been made to pursue the rule of law, human rights and constitutionalism in strategic planning and national agenda.26 Rationale behind such attempts has been to mitigate inequalities and improve the standard of living in line with human rights minimum standards in order to reduce poverty and disparities. 27 The process includes Constitutional review, law drafting, ${ }^{28}$ strategic vision 2030, enacting supportive legislations, re-invigorating institutional reforms, and venturing into judicial transformation.

The World Bank Reports reveal that the majority of individual citizens, families and groups still live in deplorable conditions according to the set-up international minimum and adequate standards. A large number of Kenyans are still unemployed and subjected to live below poverty level by all standards according to the inequality trends with 4.6\% GDP annual growth. ${ }^{29}$ Worse still, means of income do not meet the international threshold of minimum standards of living leading to poor access to social security in terms of food, water, health and housing.

Efforts to improve social welfare through law, institutions and policies always are faced with strong political resistance through corrupt deals using State powers. Gender inequality, negative ethnicity, economic, corruption, impunity, social and cultural inequalities are still grey areas in the on-going transitional justice process. ${ }^{30}$ Equal opportunity provisions, inclusive social order involving all citizens in respect to the cultural and political diversities that are still in the limbo of transitional justice are still far from practical achievement. ${ }^{31}$ Disadvantaged individuals do not benefit from the "State protection" in terms of tenure securities when it comes to land ownership and use, nor health insurance for the low-income persons. ${ }^{32}$

\footnotetext{
23 GORAN HYDEN, African Politics in Comparative Perspective, Cambridge University Press, New York, 2006, p. 314.

${ }^{24}$ IDEM.

25 Prof. Makau Mutua, Kenya's Quest for Democracy: Taming Laviathan, See

https://www.rienner.com/title/Kenya_s_Quest_for_Democracy_Taming_Le viathan

${ }^{26}$ See KENYA YEAR-BOOK, "A New Dawn for Kenya”, Kenya Year Book Editorial Board, The Government of Kenya, 2010.

${ }^{27} \mathrm{http}$ ://www.vision2030.go.ke/

28 The Constitution of the Republic of Kenya, 2010.

29 THE WORLD BANK, THE WORLD BANK GROUP, 2014 "POVERTY \& EQUITY DATABANK OF KENYA".

30 KENYA YEAR-BOOK, 2010, p. 361. "At national level gender imbalance in primary education is not very apparent as the ratio stands at 51 for boys to 49 for girls.

${ }^{31}$ Social exclusion is one of the major causes of inequality.

${ }^{32}$ KENYA HUMAN RIGHTS COMMISSIONER, “Towards Equality and
} 


\section{Prominent Questions}

Referring to contradicting inequalities and disparities in the Kenyan system and having law and order in place, it is obvious to question oneself, what is really missing? It would be inaccurate to claim that the Government is not committing itself enough to ensure enforcement of equality rights, through enhancing equality policies based on taxation, subsidized training, affirmative action, allowing practices of inequality. 33

By analogy the inequality which had moved human rights lawyers and jurist in Euro-American zone is still affecting affluent societies such as UK, USA and other modern democracies. 34 In more-or-less the same manner, Kenya hangs on historical social injustice (status quo) that has never been exhaustively addressed through existing institutions. 35 For instance, the Truth, Justice and Reconciliation Commission (TJRC) failed to deliver on its constitutional mandate allowing past abuses to determine the present and predict the future of equality rights without reconciling the past socio-economic injustice.

Art. 27 of the Constitution of Kenya reiterates equality rights underwritten in its provision: The parties are also agreed that the Constitution holds dear those who have been historically marginalised; women, youth, persons with disabilities, marginalised communities and other vulnerable persons. Article 27 requires not only equality and freedom from discrimination but affirmative action to remedy these historical wrongs. The duty of the State to ensure full participation of these groups of persons is also emphasised in Articles 54 and 56 that elaborate the rights of people with disabilities and minorities and marginalised persons respectively. 36 High Court Judges Lenaola, Ngugi and Majanja ruled: We direct the IEBC to develop a program, in conjunction with constitutional and statutory commissions and political parties, to develop policies and measures geared towards increasing the participation of women, youth, persons with disabilities, marginalised groups and other vulnerable persons to effectively participate in political processes. 37

However, claims of enforcing international minimum standards and human rights still remain main ground for academic debates and discussions in the public interest in Kenya.

Several debates highlight extreme and radical communist assumptions about a society of all equals in terms of resources, services and human security. Discussions usually

Anti-Discrimination: An Overview of International and Domestic Law on Anti-Discrimination in Kenya", http://www.khrc.or.ke; See also http://www.actionaid.dk/sw7605.asp

${ }^{33} \mathrm{Cf}$. http://www.actionaid.dk/sw7605.asp

${ }^{34}$ J.K. GALBRAITH, The Affluent Society, Penguine Books Ltd., Great Britain, 1958, p.14

Cf. Rule of Law Report 2010/2011: Transitional Justice in Kenya-Looking Ahead and Looking Back, THE KENYAN SECTION OF THE INTERNATIONAL COMMISSION OF JURISTS, pp. 111-131.

${ }^{36}$ Petition 147, of 2013 - National Gender and Equality Commission v IEBC and another [2013] eKLR, accessed at http://kenyalaw.org/caselaw/cases/view/87523

${ }^{37}$ IDEM. interpret equality rights in terms of liberal egalitarianism theory that believes in some proportional inequality in society based on the principle of equal concerns and respect meant for every member of the human family. It is certain that social classes ranging from the upper class to lower class still haunt the modern democracies many Centuries after Karl Marx whose idea expressed in the Communist Manifesto was to do away with social classes. ${ }^{38}$ Under the equality rights principle this disparity is unacceptable since the majority of the population is subjected to life that is below the established minimum standards and human rights.

Prominent questions that follow are: is the Republic of Kenya recognizing equality rights as expected? Does Kenya honour her obligations in the international human rights law? What are the equality rights? Do they make any pragmatic sense? Are they real rights or abstract rights? Are they achievable? How should we interpret them? And lastly, are they enforceable? How are the global resources shared among humans?

\section{Case Study}

The jurisprudence on social justice in Kenya is still lacking in targeted research, vigorousness and eventually political good will. Social welfare institutions such as the National Social Security Fund ${ }^{39}$ and National Health Insurance Fund ${ }^{40}$ have been dysfunctional and blamed for wide level of perpetuating patronage politics and corruption.

In a civil case involving NSSF, Civil Case No. 59 of 2005 and Hon. Justice Azangalala made the ruling in these words and I quote: "In the interests of justice and for what it is worth, I order that the status quo obtaining as of today be maintained pending the hearing of the 1 st defendant's application on 24/2/05 before any judge." ${ }^{41}$ The meaning of the status quo does not make equality rights justiciable especially in financial and economic crimes associated with institutional corruption, impunity and inequitable distribution of wealth.

In Judicial Review 81 of 2014 Justice G. V. Odunga made a ruling and I quote: All State organs and all public officers have the duty to address the needs of vulnerable groups within society, including women, older members of society, persons with disabilities, children, youth, members of minority or marginalised and vulnerable communities, and members of ethnic groups with no political power, religious or cultural communities. ${ }^{42}$

In the case involving National Gender and Equality Commission $\mathrm{v}$ Independent Electoral and Boundaries Commission \& another [2013] eKLR, the ruling made by JJ Lenaola and M. Ngugi reads, and I quote, "We direct the

38 J.K. GALBRAITH, The Affluent Society, Penguine Books Ltd., Great Britain, 1958, p. 66.

39 ("NationalSocialSecurityFundAct28of1965.pdf," n.d.)

40 ("Health-Insurance-Act.pdf," n.d.) Act No.8 of 1999 (CAP 395 R.E 2002).

$41 \mathrm{http} / / /$ kenyalaw.org/caselaw/cases/view/11398/

42 REPUBLIC OF KENYA IN THE HIGH COURT OF KENYA AT NAIROBI JUDICIAL REVIEW NO. 81 OF 2013. 
IEBC to develop a program, in conjunction with constitutional and statutory commissions and political parties, to develop policies and measures geared towards increasing the participation of women, youth, persons with disabilities, marginalised groups and other vulnerable persons to effectively participate in political processes ".43

Adjudications on equality rights violations in Kenya reveal that the process has honoured transitional justice concept but maintains its reservation on matters concerning urgency.

\section{Adjudications on Equality Rights}

In a civil suit No. 26 of 2010(o.s) on Married Women's Property Act, Kenyan High Court Justice William Musyoka in which the defendant cited Art. 45 of the Constitution and held that: "...the equality in this Article does not create nor is intended to create equal spousal ownership of property acquired during marriage regardless of which spouse has acquired and paid for it or regardless of how it has been acquired and paid for. Rather, and contrary to the assumption that it makes property acquired during marriage the property of both spouses in equal shares, it relates to and recognizes personal rights of each spouse to enjoy equal rights to property and personal freedoms and to receive equal treatment without discrimination on the basis of gender and without being shackled by repugnant cultural practices or social prejudices." 44

The High Court ruled that, in part (a) That the Plaintiff is entitled to half share beneficial interest in the property. ${ }^{45}$

In this landmark court ruling it is clear that the Judiciary is not empowered to deal with causes and roots of inequality but how it affects rights of individuals. The equality of spouses concerning Married Women's Property Rights is honoured after persuasive and well thought out equality rights principles.

It is certain that poverty, social and economic imbalance still persists and equality rights find themselves in the limbo of transitional justice contemplated in the spirit of the Constitution 2010.

\section{Judicial Enforceability}

The mainstream human rights lawyers agree that the best way to enforce equality rights is through the rule of law and constitutionalism. The example is the European Convention on Human Rights and Fundamental Freedoms that created the European Human Rights Court whose mandate includes monitoring the implementation of human rights in the member States. Probably, the African Court of Human and People's Rights based in Arusha could serve the same purpose to accelerate the implementation of Human Rights

$43 \mathrm{http}: / /$ kenyalaw.org/caselaw/cases/view/87523

${ }^{44} \mathrm{http}: / /$ kenyalaw.org/caselaw/cases/view/98462/

45 IDEM. within its member States. However, the assumption that Kenyan Judicial Authority can superimpose itself over other State organs may only result into further constitutional conflicts. The constitution has a provision on the Bill of Rights and some clauses empowering the courts to be the overseers of human rights violations but with less authority. Under Sec. 172(1)(a) Judges are recommended by the Judicial Service Commission to be appointed by the President only after the approval by the National Assembly. Under the same Section, ss. 2(b) the commission is to be guided by the promotion of gender equality.

The constitution under Section 20(3) states that in applying a provision of the Bill of Rights court shall- (a) develop the law to the extent that it does not give effect to a right or fundamental freedom; and (b) adopt the interpretation that most favours the enforcement of a right or fundamental freedom. The court shall develop the law to the extent that it does not give effect to a right or fundamental freedom is a claw-back clause that tends to contradict the duty of the court to develop the law towards promoting and protecting rights and fundamental freedom which is again corrected in clause (b) stating the enforcement. 46

In view of the judicial enforceability of the Bill of Rights the Constitution has empowered the Judiciary as an independent State organ to promote and protect human rights including equality of rights and social welfare rights. In Section 20(4)(a), a court, tribunal or other authority is mandated with the interpretation that includes the values that underlie an open and democratic society based on human dignity, equality, equity, and freedom...In this provision the judiciary is obliged by the Constitution to interpret the law in a manner that shall promote and protect equality of rights of every individual. ${ }^{47}$

The court shall be guided by the following provisions under Section 20(5); (a) It is the responsibility of the State to show that the resources are not available; (b) In allocating the resources the State shall give priority to ensure that the widest possible enjoyment of the right or fundamental freedom having regard to prevailing circumstances, including the vulnerability of particular groups or individuals, and (c) the court, tribunal or other authority may not interfere with a decision by the State organ concerning the allocation of the available resources, solely in the basis that it would have reached a different decision.

The judicial enforceability is limited under subsection (c) conditioning it not to interfere with the State with a decision by the State organ concerning the allocation of the available resources. This is a claw-back clause which gives carrot and stick at the same.

\footnotetext{
${ }^{46}$ Cf. KENYA HUMAN RIGHTS COMMISSION, "Towards Equality and Anti-Discrimination: An Overview of International and Domestic Law on Anti-Discrimination in Kenya", <http://www.khrc.or.ke>; See also VICKI C. JACKSON, Constitutional Engagement in a Transnational Era, Oxford University Press, 2010, p. 199.

${ }^{47}$ IDEM.
} 


\section{The Enforcement of Human Rights Law}

It would not make much rational sense to exhaustively discuss equality rights without linking them to the concepts of universal human rights based on already reviewed history, politics and jurisprudence of rights. As has been illustrated earlier human rights derive their meaning and justification from natural rights theory. The enforcement and constitutionality of equality rights shall only become true if difficulties impeding them are resolved.

The repealed constitution of the Republic of Kenya under its chapter $\mathrm{V}$ had a proviso on "Protection of fundamental rights and freedoms of the individual" which was not respected the Governments in power." It was good in letter but not in the spirit of the law. Actually the provision had nothing to represent promotion and protection of equality rights or the rights of the citizens and non-citizens. Excessive arbitrary State powers could not allow equality rights chance for implementation.

One of the main challenges facing enforcement of equality rights is based on the perception citizens and juridical operators have about them. Political elite have accepted with little critical analysis the doctrine of categorical sharing of State power at the national level of Government. The legislature and the judiciary used to be at the mercy of the Executive (under the repealed constitution) which could circumvent the law to favour the interests of the elite. Yet the Constitution of 2010 still has Presidential State though with lesser arbitrary powers than in the former Constitution.

It is clear that the Judiciary is still made to decide sometimes on cases that belong to political branches. However, the Judiciary is left out of retributive decisions handled exclusively by the Executive and the Legislature. In this case judicial contribution to equality rights is restricted and limited only to advisory opinion or interpretations and little to do with adjudication of cases related to violations of equality rights. This disengagement of the Judicial authority in decision making weakens the judicial powers to participate fully in the enforcement of equality rights in Kenya.

Art. 1 of the repealed constitution states that Kenya is a sovereign Republic empowering the Government and weakening individual rights. 48 The enforceability of equality rights was not only a sheer dream but a question of great life risk especially to the opposition that struggled for democratic space as it is today.

The new Constitution of 2010 reversed the sovereignty of the State from the Government to the people of Kenya, a move that enables individuals to demand their rights and make judicial claims whenever such rights are infringed by the State or an individual. But even this is still made difficult due to political will and lack of constitutionalism.

Kenya is among States that have ratified several human

48 Cf. KENYA HUMAN RIGHTS COMMISSION, "Towards Equality and Anti-Discrimination: An Overview of International and Domestic Law on Anti-Discrimination in Kenya", $<$ http://www.khrc.or.ke $>$ rights conventions and the regional Charter. It is one of the founding members of the African Charter of Human and People's Rights of 1986. Additionally, it has participated in various international conferences on issues related to human rights. Yet equality rights remains one of the most problematic areas of human rights Kenya finds difficult to implement.

\section{The Bill of Rights}

The equality rights as experienced in the Kenyan context draws its fundamental inspirations from the constitution that was promulgated on August 27th 2010 with a dedication of Chapter Four to the Bill of Rights. Section 19(1) The Bill of Rights is an integral part of Kenya's democratic state and is the framework for social, economic, and cultural policies. The constitutional Bill of Rights provisions make it mandatory that the government cannot interfere with its obligations to promote and protect human rights and cannot make legislations that are inconsistent with the constitution. The Bill of Rights highlights most of the International Bill of Human Rights anchored on the UDHR of 1948 and the UN World Conference in Vienna in 1993 on the Declaration and Programme of Action reaffirming that all Human Rights were universal, indivisible, interdependent and interrelated and its appeal to all Governments to take all appropriate measures in compliance with their international obligations and with due regard to their respective legal systems to counter intolerance and related violence based on religion or belief . Under subsection (2) its states that recognizing and protecting human rights and fundamental freedoms is to preserve the dignity of individuals and communities and to promote social justice and the realisation of the potential of all human beings. 49

The constitution of 2010 creates a shift in State power under Section 1(1) by stating that the sovereignty "all sovereign powers belong to the people of Kenya and shall be exercised only in accordance with this constitution". By this provision the executive shall not enjoy absolute powers especially over human rights. Such people's power is exercised either directly or through democratically elected members, a provision that highlights democracy in sharing of power as opposed to the repealed constitution.

The Bill of Rights under Section 19(3) states that rights and fundamental freedoms belong to each individual and are not granted by the state; do not exclude other rights and fundamental freedoms and are only subject to limitations contemplated in the constitution.

The Constitution also defines the applicability of the Bill of Rights under Section 1 (1) "The Bill of Rights applies to all law and binds all State organs and all persons; (2) Every person shall enjoy rights and fundamental freedoms in the Bill of Rights to the greatest extent consistent with the nature

\footnotetext{
49 Cf. KENYA HUMAN RIGHTS COMMISSION, "Towards Equality and Anti-Discrimination: An Overview of International and Domestic Law on Anti-Discrimination in Kenya", <http://www.khrc.or.ke>
} 
of the rights or fundamental freedoms". This is affirmation of the International Bill of Human Rights in its entirety.

Bill of Rights in the constitution of Kenya is a radical departure from the previous constitution not only in respect of its enforceability but also in the breadth and scope of its recognition, promotion and protection of rights. Under Section 255(1)(e) requires a referendum for the approval of any alteration. ${ }^{50}$

\section{Progressive Achievement of Equality Rights}

Generally it is agreed that only through democracy and rule of law that human rights can be effectively enforced and implemented but this can be achieved progressively. 51 However, lack of appropriate judicial tradition of protection of socio-economic rights and other rights in Kenya is one of the hindrances to the full implementation of the Bill of Rights and Equality Rights in particular. There is lack of long standing judicial tradition, and institutions with adequate capacity in promoting and protecting equality rights informed by the transitional justice approach. An example is the affirmative action for social development requiring women to hold $1 / 3$ of legislative assemblies.52 At the request for advisory opinion on the rule, The Supreme Court of Kenya ruled that this provision shall be implemented progressively and not immediately on the Advisory Opinion Application 2 of 2012.

In its majority opinion the Court acknowledged the, "social imperfection which led to the adoption of Articles 27(8) and 81(b) of the Constitution: that in elective or other public bodies, the participation of women has, for decades, been held at bare nominal levels, on account of discriminatory practices, or gender-indifferent laws, policies and regulations. This presents itself as a manifestation of historically unequal power relations between men and women in Kenyan society and its resultant diminution of women's participation in public affairs has had a major negative impact on the social terrain as a whole.

Despite this, majority of the Court was also of the opinion that the one third gender principle as provided for by the constitution could not be enforced immediately and was to be applied progressively: progressively being by 27 August 2015. The court stated that, "legislative measures for giving effect to the one-third-to-two-thirds gender principle, under Article 81(b) of the Constitution and in relation to the National Assembly and Senate, should be taken by 27 August, 2015.

\footnotetext{
${ }^{50}$ See KENYA HUMAN RIGHTS COMMISSION, "Towards Equality and Anti-Discrimination: An Overview of International and Domestic Law on Anti-Discrimination in Kenya", $<$ http://www.khrc.or.ke $>$

${ }^{51}$ Cf. PHILIPS ALSTON AND GERARD QUINN, "The Nature and Scope of States' Parties Obligations under the International Covenant on Economic, Social and Cultural Rights, in the Human Rights Quarterly, 9(1987), 156-229, The John's Hopkin's University Press.

${ }_{52}$ Affirmative action is government action to remedy long-standing discrimination of some groups engaging policies, programmes and procedures. This should include women, ethnic groups, jobs for minorities, admission for higher learning and the awarding of government contracts.
}

Violations of the economic, social and cultural rights adjudications tend not to consider the root causes of such offences in a process of transitional justice. Generally court rulings tend to be soft on the Government when it comes to compensations of violations linked to equality of rights in respect to economic pressure on the State and its obligations. 53

States by introducing certain policies such as medical care, construction of roads, reducing education cost, increasing budget on security, modernizing quality of education as in the budget of 12th June 2014 read in the National Assembly by the Cabinet Secretary and increasing money meant for social welfare, it is evident that this is in line with the spirit of transitional justice entrenched in the spirit of the Constitution.

Section 27(1) Every person is equal before the law and has the right to equal protection and equal benefit of the law; ( $b$ ) equality includes the full and equal enjoyment of all rights and fundamental freedoms; (3) men and women have the right to equal treatment, including the right to equal opportunities in political, economic, cultural and social spheres. This section is defining the equality rights and freedom from discrimination of which every person is entitled to.

Discrimination has been defined as follows: “...Discrimination means affording different treatment to different persons attributable wholly or mainly to their descriptions by...sex whereby persons of one such description are subjected to...restrictions to which persons of another description are not made subject or are accorded privileges or advantages which are not accorded to persons of another such description...Discrimination also means unfair treatment or denial of normal privileges to persons because of their race, age, sex... a failure to treat all persons equally where no reasonable distinction can be found between those favoured and those not favoured" 54

\section{Enforceability Challenges}

The new Constitution addresses some of the listed elements of enforcement requirements of equality rights. The Constitution of Kenya 2010 in Articles 10, 27, 43, 59 and Chapter Fifteen among others. Article 10 provides for the national values and principles of governance, which include: human dignity, equity, social justice, inclusiveness, equality, human rights and non-discrimination. Specifically, Article 27 of the Constitution sets out the principle of equality and freedom from discrimination by stating that, every person is equal before the law and has a right to equal protection and benefit under the law ${ }^{55}$. The National Gender Equality

\section{See "TRANSITIONAL JUSTICE AND ECONOMIC, SOCIAL AND CULTURAL RIGHTS" HR/PUB/13/5 UNITED NATIONS PUBLICATION SALES No. E.14.XIV.3}

54 Paragraph 91 of the REPUBLIC OF KENYA IN THE HIGH COURT OF KENYA AT NAIROBI CONSTITUTIONAL AND HUMAN RIGHTS DIVISION CONSTITUTIONAL PETITION NUMBER 160 OF 2013.

55 National Gender Equality Commission, accessed at 
Commission is a very important institution that requires equally important attention and financial support in order to make its relevant contribution in the enforcement process. The Commission is also receiving complaints and can use its constitutional power to sue the Government on matters concerning the violation of equality rights in Kenya. However, the full enforcement of equality rights is still a challenge of the present and future of the Constitution in force due to lack of funding.

The doctrine of the separation of State powers among the three State organs: the Judiciary, the Executive and the Legislature remains problematic in the Kenyan system after the most celebrated promulgation of the new constitution on 27th August 2010.56 Still the Executive and the Legislature regard the judiciary as a subordinate State organ that should be subjected to the powers of the Executive and Parliament whenever they exercise their overseeing power to establish checks and balances and to exercise their rights as democratically elected representatives of the people. Hence, independence and impartiality of the judiciary is continuously exposed to threats also from the constitutional Judicial Service Commission and the statutory vetting Board making it weaker in enforcing equality human rights that shall always ensure that the Government respects its international law obligations and coerces them through its institutions.

Courts handle cases brought before them for adjudication, advisory opinion, interpretation, inter alia but judges use their discretion to refrain from actions that may put them in conflict with the interests of the Executive, the Legislature or any other political branch. Separation of State powers, autonomy and independence of judges under the principle of impartiality of judges are key frustrations facing the judicial enforceability of equality rights in Kenya.

There is cost on the part of the emerging States (Statu Nascendi) to ensure that there is full enjoyment of socio-economic and cultural rights. For instance, everyone is entitled to decent housing that will promote his or her human dignity shall necessarily require funding from the State. Social security for unemployed citizens shall require the State to allocate some social welfare funds to this cause. However, given the poverty level in Kenya and low economic growth may not enable State authority to guarantee the protection of basic equality rights.

It would be appropriate for Kenya in the new constitutional dispensation premised on the rule of law, human rights and constitutionalism to ratify Optional Protocols and other related international law conventions. It is the Government to come up with policy framework that would enhance more public confidence in equality rights.

Creating a comprehensive and credible framework for

http://www.ngeckenya.org/about/15/Mandate

56 BARON DU MONTESQUIEU accessed at:http://en.wikipedia.org/wiki/Separation of powers under the United S tates_Constitution; See also PHILIPS ALSTON AND GERARD̄ QUINN "The Nature and Scope of States' Parties Obligations under the International Covenant on Economic, Social and Cultural Rights, in the Human Rights Quarterly, 9(1987), 156-229, The John's Hopkin's University Press. complainant mechanism and training are necessary causes that must be fulfilled in light of the National Gender Equality Commission and other relevant institutions. The commissions are quasi-judicial bodies that can facilitate the enforcement of equality rights. This can be supported by the constitutional provision on the access to justice holding the Government accountable of its obligations and commitment to human rights under Section 48 yet the operations of transition justice.

The United Nations has defined transitional justice as "the full range of processes and mechanisms associated with a society's attempt to come to terms with a legacy of large-scale past abuses, in order to ensure accountability, serve justice and achieve reconciliation. $", 57$

It is within the powers of the state to prevent violations to equality rights, protect and promote such rights within its jurisdiction through transitional justice mechanisms. This may include national budget allocations with clear policy objectives to ensure enforcement of equality rights. Improving job creation, improving basic education, and enhancing access to justice are some of the transitional justice approaches to enforce the equality rights if performed in good faith.

Professor T. W. Bennett, African Customary Law should not be ignored in the law and institutional reforms. African Customary law would create more jurisprudence on equality human rights and how to translate it into the domestic system for its better apprehension, legitimacy and enforcement. He opines that an absence of rules and an emphasis on tradition do not mean that the individual will suffer mistreatment under African customary law. ${ }^{58}$

The difficulty in enforcing equality rights is related also to the weaknesses of the African Charter on Human and Peoples' Rights. African political leaders tend to think that they can always use self-determination, self-rule and independence, meaning political independence to violate or go against human rights. ${ }^{59}$ The notion of sovereignty of the State has changed in the time of global justice system and African States may no longer find it reasonable to defend themselves using sovereignty as a human rights shield as Daniel Don Nanjira rightly puts it. ${ }^{60}$

\section{Conclusive Remarks}

It is apparently clear in the Constitution that the Bill of Rights rules that the State is charged with the duty to promote and protect equality rights and ensure that every individual also does the same. Remaining faithful to the approved transitional justice system to the enforcement of equality rights one of the achievements of the constitution of

${ }^{57}$ THE UNITED NATIONS HUMAN RIGHTS OFFICE OF THE HIGH COMMISSIONER, "Transitional Justice and Economic, Social and Cultural Rights.

${ }_{58}$ T.W. BENNETT, African Customary Law, p. 3.

${ }^{59}$ DANIEL D.C. DON NANJIRA, "The Protection of Human Rights in Africa: The African Charter on Human and People's Rights", in JANUSZ SYMONIDES, p.226.

${ }^{60}$ IDEM. 
2010 includes devolution of resources to the 47 counties and sharing of State powers among constitutional organs. The same Constitution makes it obligatory to enact legislations that would create appropriate and stronger institutions such as Constitution Implementation Commission, Kenya National Human Rights and Equality Commission, ${ }^{61}$ National Gender and Equality Commission, Ethics and Anti-Corruption Commission ${ }^{62}$, National Lands Commission, National Cohesion and Integrity Commission, National Revenue Commission, Salary and Remuneration Commission, Judicial Service Commission, Independent Boundary and Elections Commission, National Police Service Commission (under the sixth Schedule) and Truth, Justice and Reconciliation Commission (TJRC) . Kenya has institutions that if properly managed and appropriately empowered can make substantive contribution to the implementation of equality rights and spur her development goals. However the effectiveness of such mechanisms and quasi-judicial approaches rely on good faith of politicians since they are always abused with impunity and their reports often lack implementation.

Equality rights appertain by its idiosyncratic essence to the universal human rights conceptions that are in themselves difficult to enforce especially in conditions of inequality, corruptions, impunity and historical social injustice such as in Kenya. Despite the constitutionality of the equality provisions and relevant legislations, still its enforceability is faced with various substantial challenges and prominent questions that may require in furtherance, more discussions and debates. ${ }^{63}$ The judiciary does not have full power to protect and promote equality provisions without the good will of the executive and the parliament. It is also a reality that the judiciary requires more enacted laws to deal with complaints of human rights including enacting Human Rights Act to strengthen the Bill of Rights.

While it is reasonable to rule that equality rights can only be implemented in a progressive manner in respect to transitional justice concept, it is also imperative to admit that the State still needs to show more commitment to her international obligations to human rights. The best understanding of progressive implementation of economic, social and cultural rights can be found in the concept of transitional justice but this should not be the "end justifies the means" but rather, the "means justifies the end". ${ }^{64}$

There is no doubt that the political will is the bottom line of all the human rights allegations ${ }^{65}$ especially concerning the most enchanted equality rights, equitable distribution

\footnotetext{
${ }^{61} \mathrm{http}: / / w w w . n g e c k e n y a . o r g /$

62 ("Anti-CorruptionandEconomicCrimesAct3of2003.pdf," n.d.)

${ }^{63}$ Cf. DAVID KEANE \& YVONNE MCDERMOTT, The Challenge of Human Rights: Past, Present and Future, Edward Elgar Publishing Limited, Massachusetts, USA, 2012, p.2.

64 UNITED NATIONS HUMAN RIGHTS OFFICE OF THE HIGH COMMISSIONER, "Transitional Justice and Economic, Social and Cultural Rights; accessed http://www.ohchr.org/Documents/Publications/HR-PUB-13-05.pdf 65 VICKI C. JACKSON, Constitutional Engagement in a Transnational Era, Oxford University Press, 2010, p. 31, "Organic Conception of Law", the authority of the law giver overshadows the connection of the law with the society, cultural connections, totally missing the spirit of people.
}

income, provision of social welfare state and respect for human rights. Political powers compete for numbers they have in Parliament to influence equality rights in the interest of the constitutional majoritarian democracy and estrange themselves from the spirit of the people. The tyranny of number in the Kenyan Government is a reality that excludes the minority rights and may lead to conflicts, unfairness in enforcing equality rights and imbalances in the way human rights law is engaged.

Pace-setting policy agenda as vision 2030 may as well be decorative approaches to development if they do not recognize equality rights. They lack concrete applicability given the dwindling economic growth, lack of rational seriousness, wider consultations and accommodating status quo identified with high level of corruption and failure to optimize operating administrative system. Reluctance in reforming police, governance, and to embrace constitutionalism and the rule of law, is a failure to show seriousness in implementing equality rights. 66

\section{REFERENCES}

[1] <http://kenyalaw.org/caselaw/cases/view/85286>

[2] <http://www.mzalendo.com/blog/2012/12/14/on-the-s upreme-courts-majority-opinion-on-the-one-third-gend er-rule/

$<$ http://www.judiciary.go.ke/portal/one-third-gender-r ule.html>

[3] <https://www.youtube.com/watch?v=NFLDFYyr7tQ $>$

[4] <https://www.youtube.com/watch?v=NFLDFYyr7tQ $>$ DR. JOHN FINNIS lecture on "Equality and Issues of Life: A Scorecard".

[5] <https://www.youtube.com/watch?v=NFLDFYyr7tQ $>$

[6] <https://www.youtube.com/watch?v=NFLDFYyr7tQ >

[7] <https://www.youtube.com/watch?v=NFLDFYyr7tQ >

[8] ADAM SMITH, The Wealth of Nations, Bantam Dell, New York, 2003.

[9] DR. PETER ONYANGO (PhD), African Customary Law System: An Introduction, LawAfrica Publishing Ltd (K), Nairobi, 2013.

[10] DAVID KEANE \& YVONNE MCDERMOTT, The Challenge of Human Rights: Past, Present and Future, Edward Elgar Publishing Limited, Massachusetts, USA, 2012.

[11] DR. PETER ONYANGO (PhD), Cultural Gap \& Economic Crisis in Africa: Focus on the sub-Saharan Region, FastPrint Publishing, UK, 2010.

[12] FONS COOMANS (Ed.), Justiciability of Economic and Social Rights: Experience from Domestic Systems, Oxford University Press, UK, 2006, p. 1.

$66 \mathrm{http} / / / \mathrm{www} . v i s i o n 2030 . g o . k e /$ index.php/vision 
[13] GORAN HYDEN, African Politics in Comparative Perspective, Cambridge University Press, New York, 2006 , p. 314.

[14] JOHN RAWLS, A Theory of Justice, The Belkanap Press of Harvard University Press, USA, 1999, p. 73.

[15] J.K. GAlBRAITH, The Affluent Society, Penguine Books Ltd., Great Britain, 1958.

[16] JANUSZ SYMONIDES (Ed.), Human Rights: International Protection, Monitoring, Enforcement, UNESCO Publishing, 2003. Quoted DANIEL DON NANJIRA, "The Weaknesses of the African Charter on Human and People's Rights", pp. 213-236.

[17] KENYA YEAR BOOK, A NEW DAWN FOR KENYA, Kenya Editorial Board, The Government of Kenya, 2010.

[18] MALCOLM N. SHAW, International Law, A Grotius Publication, Cambridge University Press, 1997, 4th Edition, p. 207.

[19] MARTHA F., DAVIS, "Participation, Equality, and the Civil Rights to Counsel: Lessons from Domestic and International Law", Yale Law Journal, USA, June 1, 2013, pp. 2262-2281.

[20] MICHAEL J. DENNIS AND DEVID P. STEWART, "Justiciability of Economic, Social and Cultural Rights: Should there be an International Complaints Mechanism to Adjudicate Rights to Food, Water, Housing, and Health?"in $<$ http://heinonline.org/HOL/Page?handle $=\mathrm{h}$ ein.journals/ajil98\&div $=44 \& g$ _sent $=1 \&$ collection $=$ jou rnals $\# 472>$.

[21] MICHAEL KENNY, "Gender Equality and Social Exclusion Issues in Rural Development", National University of Ireland, Maynooth.

[22] OKOTH-OGENDO, HASTINGS WO. Constitutions without constitutionalism: reflections on an African political paradox. American Council of Learned Societies, 1988.

[23] OMONY, JOHN PAUL, Key Issues in Jurisprudence: An In-Depth Discourse on Jurisprudence Problems, LawAfrica Publishing, 1st Edition, p. 19.

[24] PHILIPS ALSTON AND GERARD QUINN, "The Nature and Scope of States' Parties Obligations under the International Covenant on Economic, Social and Cultural Rights, in the Human Rights Quarterly, 9(1987), 156-229, The John's Hopkin's University
Press.

[25] PROF. EDWIN O. ABUYA, "From Here to Where? Refugees Living in Protracted Situations in Africa", in EDWARDS, A. \& CARLA, F. (EdS.), Human Security and Non-Citizen Law, Policy and International Affairs, Cambridge University Press, 2010, PP. 125-165. Cited page 125 "some refugee situations have considerable time to resolve."

[26] PROF. KIVUTHA KIBWANA, Fundamental Rights and Freedoms in Kenya, Oxford University Press, Nairobi, 1990.

[27] PROF. MAKAU MUTUA, Kenya's Quest for Democracy: Taming Laviathan, See https://www.rienner.com/title/Kenya_s_Quest_for_De mocracy_Taming_Leviathan

[28] RHONA K.M. SMITH \& CHRISTIEN VAN DER ANKER, The Essentials of Human Rights, Hodder Arnold, Oxford University Press, USA, 2005, p. 108.

[29] RICHARD N. RWIZA, Ethics of Human Rights: The African Contribution, CUEA, Nairobi, 2010, p. 174."

[30] T.W. BENNETT, Human Rights and African Customary Law: Under the South African Constitution, Law Series of the Community Law Centre, University of the Western Cape, JUTA \& Co. Ltd., 1995, p.3.

[31] The Constitution of the Republic of Kenya, 1963 (Repealed).

[32] The current Constitution of the Republic of Kenya, 2010.

[33] THE KENYAN SECTION OF THE INTERNATIONAL COMMISSION OF JURISTS, Nairobi, 2005, pp. $1 \mathrm{ff}$.

[34] Rule of Law Report 2010/2011: Transitional Justice in Kenya-Looking Ahead and Looking Back, THE KENYAN SECTION OF THE INTERNATIONAL COMMISSION OF JURISTS, pp. 111-131.

[35] VICKI C. JACKSON, Constitutional Engagement in a Transnational Era, Oxford University Press, 2010.

[36] WOJCIECH SADURSKI (Ed.), Constitutional Theory, European University Institute, Italy and University of Sydney, Australia, Ashgate, Dartmouth, 2005.

[37] The Marriage Act of 2014 Laws of Kenya.

[38] UNITED NATIONS UNIVERSAL DECLARATION OF HUMAN RIGHTS, 1948. 